\title{
SURVEI PROSES PEMBELAJARAN PENDIDIKAN JASMANI ADAPTIF DI SDLB C KABUPATEN SRAGEN TAHUN 2019/2020
}

Nur Alima , Arif Rohman Hakim S.Or. M.Pd ${ }^{b}$, Karlina Dwijayanti S.Pd., M.Or ${ }^{c}$

a Physical Education, Universitas Tunas Pembangunan Surakarta, Surakarta, Indonesia.

${ }^{b}$ Physical Education, Universitas Tunas Pembangunan Surakarta, Surakarta, Indonesia.

Email:a nuralim1518@gmail.com

\begin{tabular}{l}
\hline I N F O A R T I K E L \\
\hline Sejarah artikel: \\
Menerima 1 Januari 2021 \\
Revisi 21 Januari 2021 \\
Diterima 31 \\
Online 1 Februari 2021 \\
\hline Kata kunci: \\
Pembelajaran, Jasmani, \\
Adaptif.
\end{tabular}

Keywords:

Learning, Physical, Adaptif.

\footnotetext{
Style APA dalam mensitasi artikel ini: [Heading sitasi] Satu, N. P., \& Dua, N. P. (Tahun). Judul Artikel. Register: Jurnal Ilmiah Teknologi Sistem Informasi, $\mathrm{v}(\mathrm{n})$, Halaman awal Halaman akhir. [heading Isi sitasi]
}

\section{ABSTRAK}

Penelitiam ini bertujuan untuk mendeskripsikan mengenai pelaksanaan pembelajaran Pendidikan jasmani adaptif anak tuna grahita. Penelitian ini adalah penelitian deskriptif kualitatif. Penelitian ini dilakukan di SDLB C Kabupaten Sragen yaitu: YPSLB C Gemolong, SLB B-C Bagaskara, SLB Negeri Sragen dari bulan Juli sampai Agustus 2020. Informan dalam penelitian ini adalah guru mata pelajaran Pendidikan jasmani adaptif, guru kelas, dan wali murid.

Pengumpulan data pada penelitian ini adalah mengunakan wawancara, observasi dan dokumentasi. Validasi data pada penelitian ini yaitu Triangulasi data yang terdiri dari triangulasi sumber, triangulasi Teknik, triangulasi waktu.

Hasil penelitian menunjukan bahwa pelaksanaan pembelajaran tergolong baik, pembelajaran di lakukan sesuai dengan jenis ketunaan peserta didik, sedangkan fasilitas sarana dan prasarana dasar penunjang pembelajaran penjas adaptif untuk di SLB Negeri Sragen dan SLB B-C Bagaskara sudah cukup lengkap dan YPSLB Gemolong kurang lengkap. Pelaksanaan pembelajaran di SLB Negeri Sragen, SLB B-C Bagaskara dan YPSLB Gemolong sudah memisahkan pembelajaran berdasarkan jenis ketunaan peserta didik, Namun belum bisa maksimal daan kondusif karena guru mengalami kesulitan dalam mengenadalikan peserta didik. Untuk sarana dan prasarana di sekolah mayoritas sudah baik di SLB Negeri Sragen dan SLB B-C Bagaskara Sragen sudah memiliki fasilitas sarana dan prasarana penunjang pembelajaran penjas adaptif, sedangkan di YPSLB Gemolong sarana prasarana belum terlalu lengkap karena belum tersedia lapangan untuk bermain, olahraga dan upacara secara khusus dan terpisah, peralatan atletik juga belum lengkap sehingga agak susah untuk melaksanakan pembelajaran secara maksimal.

Kata kunci: Pembelajaran, Jasmani, Adaptif.

\section{ABSTRACT}

This research aims to describe the implementation of adaptive physical education learning for mentally disabled children. 
This research is a qualitative descriptive study. This research was conducted at SDLB $C$, Sragen Regency, namely: YPSLB C Gemolong, SLB B-C Bagaskara, SLB Negeri Sragen from July to August 2020. The informants in this study were adaptive physical education subject teachers, classroom teachers, and student guardians. Collecting data in this study using interviews, observation, and documentation. Data validation in this study is data triangulation consisting of source triangulation, technical triangulation, time triangulation.

The results showed that the implementation of learning was classified as good, learning was carried out according to the type of disability of students, while the basic facilities and infrastructure for supporting adaptive physical education learning at SLB Negeri Sragen and SLB B-C Bagaskara were quite complete and YPSLB Gemolong was not complete. The implementation of learning at SLB Negeri Sragen, SLB B-C Bagaskara, and YPSLB Gemolong has separated learning based on the type of disability of students, but the results have not been maximally conducive because teachers have difficulty in controlling students. For the facilities and infrastructure in schools, the majority are good at SLB Negeri Sragen and SLB BC Bagaskara Sragen already have facilities and infrastructure to support adaptive physical education learning, while at YPSLB Gemolong the facilities are not too complete because there is no field for playing, sports and special ceremonies. and separately, athletic equipment is also incomplete so it is rather difficult to carry out learning optimally.

Keywords: Learning, Physical, Adaptif.

\section{Pendahuluan}

Pendidikan pada dasarnya bertujuan untuk semua orang di mulai dari anak kecil sampai orang tua. Pendididkan tidak hanya berasal dari bangku sekolah saja, namum juga bisa di peroleh dari interaksi sosial yang terjadi di dalam kehidupan bermasyarakat. Seperti yang tertera dalam Undang Undang Sistem Pendidikan Nasional No.20 Tahun 2003 bahwa setiap peserta didik berhak mendapatkan pendidikan yang bermutu, artinya setiap peserta didik harus mendapatkan layanan yang berkualitas tidak terkecuali peserta didik berkebutuhan khusus. Selain itu pendidikan tidak di batasi oleh usia karena pendidikan ditujukan untuk semua kalangan dan semua usia. Tidak semua anak dilahirkan kedunia ini dalam keadaan sempurna, teryata ada dari anak itu di lahirkan yang mempuyai kekurangan, baik perkembangan fisik maupun mentalnya. Anak yang demikian di sebut dengan nama Anak Berkebutuhan khusus (ABK). 
Nur Alim, Arif Rohman Hakim, Karlina Dwijayanti

Berdasarkan Undang Undang No. 20 tahun 2003 tentang sistem pendidikan Nasional disebutkan bahwa pendidikan merupakan suatu usaha sadar dan terencana untuk mewujudkan suasana belajar dan proses pembelajaran agar peserta didik secara aktif mengembangkan potensi dirinya untuk memiliki kekuatan spiritual keagamaan, pengendalian diri, kepribadian, kecerdasan, ahklak mulia, serta kertampilanyang diperlukan dirinya, masyarakat, bangsa dan Negara. Anak adalah mahluk yang sedang tumbuh, oleh karena itu pendidikan sangat penting sekali karena mulai dari bayi mereka belum dapat berbuat sesuatu untuk kepentingan dirinya, baik untuk mempertahankan hidup mandiri maupun merawat diri, semua kebutuhan masih tergantung pada orang tua. Dengan demikian, anak tentunya membutuhkan sebuah bantuan, tuntunan, serta pelayanan dan drorongan dari orang lain. Tujuannya untuk mempertahankan hidup dengan mendalami tahap demi tahap guna memperoleh kepandaian, keahlian pembentukan sikap serta tingkah laku. Dengan begitu, lama kelamaan bisa melakukan aktivitas secara mandiri dan tidak membutuhkan pertolongan dari orang lain lagi.

Sedangkan orang tua mempuyai hati nurani yang terdalam yang mempuyai sifat kodrat untuk mendidik anaknya baik segi psikis, sosial, emosi maupun intelegensinya agar memperoleh kepintaran dan dapat meraih apa yang di inginkan anak sehingg aada tanggung jawab atas hadirnya anak yang di berikan oleh Allah S.W.T, untuk dapat di didik dan di besarkan dengan sebaik baiknya.

Anak berkebutuhan khusus mempuyai hak dan kewajiban yang sama dengan anak normal dalam memperoleh baik pendidikan maupun pembelajaran di Negara ini. Anak Berkebutuhan khusus sama dengan anak anak normal, yang memerlukan penjagaan atau pemeliharaan, pembinaan, asuhan, dan pendidikan yang sempurna sehingga Anak Berkebutuhan Khusus dapat menjadi manusia yang mandiri dan berdiri sendiri tanpan adanya bantuan dan pertolongan orang lain. Anak berkrbutuhan khusus mendambakan hidup yang layak seperti orang norman lainya. Oleh karena itu mereka membutuhkan pendidikan dan bimbingan dari orang lain agar bisa menjadi manusia yang dewasa, mandiri dan menjadi warga Negara yang dapat berpartisipasi dalam memajukan dan membangun bangsa dan Negara.

Pendidikan bagi anak berkubutuhan khusus bisa di lakukan dari keluarga, masyarakat, dan sekolah. Untuk pendidikan formal bagi anak berkubutuhan khusus biasanya di berikan oleh yayasan atau sekolah luar biasa (SLB). Setiap sekolah luar biasa mempunyai kurikulum pendidikan dalam mendidik, melatih anak berkebutuhan khusus. Termasuk di 
dalam progam pendidikan jasmani bagi anak berkebutuhan khusus (pendidikan jasmani adaptif).

Aktifitas gerak dalam pendidikan jasmani adaptif yang di berikan pada anak berkebutuhan khusus merupakan suatu alat untuk membantu anak dalam malanjutkan kelangsungan hidup meraka. Gerak yang di lakukan saat pembelajaran olahraga sangatlah penting bagi tumbuh dan perkembangan anak berkebutuhan khusus. Anak berkebutuhan khusus (ABK) memiliki masalah dengan sensorik, motarik belajarnya dan tingkah lakunya, keberhasilan anak berkebutuhan khusus dalam melakuakan gerak tentunya di dukung oleh peran seorang guru dalam pendidikan jasmani yang ikut berperan dalam pelaksanaan pendidikan jasmani.

Fakta di lapangan menunjukan bahwa tenaga pengajar (guru) yang mengajar mata pelajaran pendidikan jasmani adaptif di Kabupaten Sragen sebagian berlatar belakang pendidikan kepelatihan olahraga. Hal ini mengakibatkan adanya kendala dalam melaksanakan pembelajaran pendidikan jasmani.

Sragen merupakan salah satu kabupaten yang menyelengarakan pendidikan jasmani bagi anak berkebutuhan khusus (ABK). Layanan pendidikan di kabupaten Sragen terdapat 6 SLB yaitu 1 SLB Negeri dan 5 SLB Swasta. Masing masing jenjang pendidikan SDLB, SMPLB, SMALB di Sragen merupakan sekolah menengah pertama yang peduli terhadap pentinya pendidikan bagi anak berkebutuhan khusus.

Pendidikan bagi anak berkebutuhan khusus sangat penting karena mereka mempuyai tingkat kecerdasan di bawah rata rata anak normal terutama anak tuna grahita. Anak berkebutuhan khusus memerlukan kurikulum, tenaga pendidik, dan saran prasarana khusus yang telah di sesuaikan dengan jenis ketunaan anak tersebut.

Berdasarkan hasil observasi yang di lakukan oleh peneliti kemarin di peroleh informasi bahwa proses pembelajaran untuk pelajaran pendidikan jasmani adaptif di SDLB C kabupaten Sragen masih banyak menemui kendala, di antaranya minimnya saran dan prasarana yang menunjang dalam proses pembelajaran pendidikan jasmani adaptif, pelaksanaan pendidikan jasmani adaptif masih mengabungkan peserta didik dari berbagai jenis ketunaan, tentunya ini akan mengakibatkan pelasaksanaan pendidikan jasmani yang di laksanakan kurang sesuai dengan kebutuhan Anak Berkebutuhan Khusus (ABK).

Pendidikan jasmani adaptif anak berkebutuhan khusus berbeda dengan pendidikan jasmani anak normal pada umumnya. Perbedaan pendidikan anak berkebutuhan khusus 
Nur Alim, Arif Rohman Hakim, Karlina Dwijayanti

dengan anak normal dapat di lihat dari tujuan pembelajaran yang di capai, modifikasi materi yang di ajarkan, sarana prasarana, evaluasi pembelajaran.

Berdasarkan uraian di atas, maka peneliti tertarik untuk melakukan penelitian dengan judul" Survei Proses Pembelajaran Pendidikan Jasmani Adaptif di SDLB C Kabupaten Sragen Tahun 2020".

Menurut Yani dan Caryoto (2013): Tunagrahita adalah individu yang memiliki integritas yang signifikan berada dibawah rata-rata serta dengan ketidakmampuan anak untuk beradaptasi perilaku yang muncul dalam masa perkembangan.

Elly Sari Melinda (2013) menyebutkan bahwa pembelajaran adaptif merupakan pembelajaran biasa yang di modifikasi dan di rancang sedemikian rupa sehingga dapat di pelajari, dilaksanakan dan memenuhi kebutuhan pendidikan Anak Berkebutuhan Khusus (ABK). Pembelajaran adaptif bagi anak ABK hakikatnya adalah pendidikan khusus karena pendidikan yang memberikan layanan khusus.

Pendidikan jasmani adaptif adalah sebuah progam yang bersifat individual yang meliputi fisik/jasmani, kebugaran gerak, pola dan ketrampilan dasar, ketrampilan dalam aktifitas air, menari, permainan olahraga baik individu maupun beregu yang didesain bagi anak penyandang cacat. (Arif Rohman Hakim, 2017).

Pendidikan jasmani adaptif itu penting untuk menanamkan nilai nilai dan sikap positif terhadap keterbatasan, kemampuan baik dari segi fisik maupun mentalnya bersosialisasi dengan lingkungan sekitar dan memiliki rasa percaya diri dan harga diri. Seorang guru pendidikan jasmani adaptif selayaknya dapat membantu peserta didiknya agar tidak merasa rendah hati dan dikucilkan dari lingkungannya, melalui pendidikan jasmani adaptif yang mengandung unsur kegembiraan dan kesenangan, peserta didik dapat memahami dan mengatasi masalah-masalah yang dihadapi dalam kehidupan serta mengoreksi kelainan yang dialami setiap anak Beltasar Tarigan (2016: 13).

Menurut Arif Rohman Hakim (2017: 7) tujuanan khusus Pendidikan jasmani adaptif adalah:

1) Untuk menolong siswa menolong mengoreksi kondisi yang dapat diperbaiki.

2) Untuk membantu siswa melindungi diri sendiri dan kondisi apapun yang akan memperburuk keadaan melalui aktifitas jasmani tertentu.

3) Memberikan kesempatan untuk belajar dan turut berpartisipasi dalam berbagai jenis olahraga dan aktivitas jasmani dan rohani. 
4) Untuk membantu peserta didik dalam memahami kekurangan kemampuan jasmani dan mentalnya.

5) Untuk membantu peserta didik melakukan adaptasi lingkungan sosial dan mengembangkan rasa percaya diri.

Berikut ini jenis materi bagi anak berkebutuhan khusus menurut Beltasar Tarigan (2016) yaitu:

Tabel 2.1. Aktifitas Gerak

\begin{tabular}{|c|c|c|}
\hline NO & KATEGORI & AKTIFITAS GERAK \\
\hline 1. & Perkembangan gerak & $\begin{array}{l}\text { a. Gerakan yang berpindah tempat } \\
\text { yang satu ketempat yang lain } \\
\text { b. Gerakan yang tidak memelukan } \\
\text { perpindahan tepat } \\
\text { c. Gerakan keseimbangan tubuh. }\end{array}$ \\
\hline 2. & $\begin{array}{l}\text { Olahraga } \\
\text { permainan }\end{array}$ & $\begin{array}{l}\text { a. Olahraga permainan yang } \\
\text { bersifat kreatif dan inovatif } \\
\text { b. Olahraga dan yang melibatkan } \\
\text { orang banyak/ beregu } \\
\text { c. Olahraga dan permainan yang } \\
\text { mengunakan media air } \\
\text { d. Permainan membuat lingkaran } \\
\text { e. Olahraga dan permainan yang } \\
\text { mengunakan alat-alat } \\
\text { f. Olahraga senam kesegaran } \\
\text { jasmani dan aerobic }\end{array}$ \\
\hline 3. & $\begin{array}{l}\text { Kebugaran dan } \\
\text { kemampuan gerak }\end{array}$ & $\begin{array}{l}\text { a. aktifitas yang meningkatkandan } \\
\text { membentuk kelentukan } \\
\text { b. aktifitas yang dapat } \\
\text { meningkatkan kelincahan } \\
\text { c. aktifitas yang bisa meningkatkan } \\
\text { kecepatan } \\
\text { d. aktifitas yang bisa meningkatkan } \\
\text { kekuatan }\end{array}$ \\
\hline
\end{tabular}




\begin{tabular}{|l|l|l|}
\hline & $\begin{array}{c}\text { e. aktifitas yang meningkatkan } \\
\text { daya tahan tubuh }\end{array}$ \\
\hline
\end{tabular}

Menurut Yani dan Caryoto (2013: 18) Tunagrahita adalah seorang anak yang memiliki integritas yang tinggi berada dibawah rata rata dan serta dengan ketidak ada kemampuan untuk beradaptasi prilaku yang muncul dalam masa perkembanga.

1) Klasifikasi tunagrahita

Menurut Jati Rinakri Atmaja (2018: 100) dapat di klasifikasikan sebagai berikut:

a) Anak tunagrahita mampu didik IQ 68-52 adalah anak tunagrahita yang tidak mampu mengikuti pada progam sekolah biasa, tetapi ia masih memiliki kemampuan yang dapat dikembangkan melalui pendidikan walaupun hasinya tidak maksimal.

b) Anak tunagrahita mampu latih IQ 51-36 adalah anak tunagrahita yang memiliki kecerdasan sedemikian rendahnya sehingga tidak bias mengikuti progam yang ditujukan pada anak tunagrahita mampu didik. Tunagrahita mampu didik yang perlu dilatih makan, pakaian, tidur, mandi sendiri.

c) Anaktunagrahita mampu rawat IQ 39-25 adalah anak tunagrahita jenis ini memiliki kecerdasan sangat rendah sehingga ia tidak bias mengurusi diri sendiri atau sosialisasi dengan lingkungan sekitar. Untuk mengurus kebutuhan diri sendiri sangan membutuhkan orang lain.

2) Penyebab Tunagrahita

a) Penyebab genetic dan kromosom

Tunagrahita jenis ini disebabkan oleh faktor genetic yang dikenal dengan phenylketonuria. Hal ini merupakan suatu kondisi yang disebabkan oleh factor gen bawaan dari kedua orang tua sehingg mengalami kekurangn produksi enzim yang memproses protein dalam tubuh sehingga terjadinya penumpukan asam yang disebut asam phenylpyruvic.

b) Penyebab pada prakelahiran

Penyebab pada prakelahiran terjadi ketika pembuhaan. Hal yang paling bahaya adalah adanya penyakit Rubela (campak jerman) pada janim. Selain itu adanya infeksi penyakit Sifilis.

c) Penyebab pada kelahiran 
Penyebab dan faktor terjadinya tunagrahita pada anak saat kelahiran adalah kelahiran prematur, adanya masalah proses kelahiran anak seperti kekurangan oksigen saat dilahiran yang dibantu oleh alat alat kedokteran yang beresiko terhadap anak yang menimbulkan trauma pada kepala.

3) Ciri ciri anak tuna grahita menurut Elly Sari Melinda (2013: 46).

a) penampilan fisik tidak seimbang misalnya kepala terlalu kecil/besar.

b) tidak dapat mengurus diri sendiri sesuai usia.

c) tidak ada/kurang sekali perhatian terhadap lingkungan.

d) kordinasi gerakan kurang (gerakan sering tidak terkendali).

4) Klasifikasi Anak Tuna Grahita

Menurut Kemis dan Ati Rosnawati (2013: 11). Pengolongan anak tuna grahita untuk keperluan pembelajaran sebagai berikut:

a) Educable

Anak pada kelompok ini masih mempuyai kemampuan dalam akademik setara dengan anak regular pada kelas 5 Sekolah Dasar.

b) Trainable

Anak pada kategori yang ini mempunyai kemampuan dalam mengurus diri sendiri, dan dapat menyesuaikan dengan lingkunga sosial. Sangat terbatas kemampuanya untuk mendapatkan pendidikan secara akademik.

c) Custodial

Dengan pemberian latihan yang terus menerus dan khusus, dapat melatih anak rentang dasar cara menolong diri sendiri dan kemampuan yang bersifat komukatif.

\section{Metode}

Jenis penelitian ini merupakan penelitian kualitatif deskriptif, menurut Sugiyono (2018) mendefinisikan penelitian kualitatif deskriptif yaitu metode yang digunakan untuk mendapatkan data yang mendalam, suatu data yang dapat mengandung makna, makna adalah data yang sebenar-sebenarnya, data yang pasti merupakan suatu nilai yang tampak dari hasil data yang sebenarnya. Metode yang digunakan dalam penelitian ini adalah Survai. Sampel dalam penelitian ini guru olahraga, guru kelas, dan wali murid. Teknik pengumpulan data dalam penelitian ini wawancara, observasi dan dokumentasi. Sedangkan 
Nur Alim, Arif Rohman Hakim, Karlina Dwijayanti

untuk validasi data mengunakan triangulasi yaitu triangulasi sumber, triangulasi Teknik, triangulasi waktu.

\section{Hasil dan Pembahasan}

\section{Guru Olahraga}

Tujuan pembelajaran, pembelajaranya sudah menyesuaikan dengan jenis ketunaan anak. Pembelajaran menggunakan metode kooperatif yaitu pembelajaran berkelompok dengan tujuan agar peserta didik dapat berbaur dengan teman, menyesuaikan diri dengan lingkungan sekitar. Pembelajaran penjas adaptif sudah disesuaikan dengan porsi ketunaannya maka tidak menimbulkan keparahan pada tiap jenis ketunaan peserta didik.

Materi pembelajaran, untuk materi yang disampaikan sudah memberikan materi pembelajaran sesuai dengan jenis ketunaannya dan gerak peserta didik tidak dibatasi untuk menggali kompetensi anak dan menunjang pengembangan prestasi khususnya pada penjas adaptif. Materi atletik, renang dan basket tidak diajarkan di semua SLB karena keterbatasan sarana prasarana.

Kompetensi guru juga menyusun Rencana Pelaksanaan Pembelajaran (RPP) sebagai pedoman dalam melaksanakan pembelajaran pada peserta didik. Guru juga melakukan apresepsi tentang materi yang akan diajarkan pada hari itu. Metode yang digunakan guru adalah simulasi dan komando dengan tujuan agar peserta didik lebih tertarik dengan materi. Guru juga memanfaatkan sumber belajar di sekitar lingkungan untuk pembelajaran, misalnya kardus sebagai bahan lompat, dan botol untuk permaianan estafet. Guru juga mendiskusikan perkembangan peserta didik agar sama sama dapat memantau perkembangan anak. Guru juga mengetahui kelemahan peserta didik untuk mengetahui kompetensi dan menentukan pengajaran yang sesuai dengan jenis ketunaannya.

Sarana dan prasarana semua SDLB Kabupaten Sragen sudah memiliki sarana prasarana minimal untuk melakukan pembelajaran penjas adaptif dan memodifikasi alat olahraga yang sesuai dengan kemampuan dan jenis ketunaan peserta didik.

evaluasi pembelajaran dan guru juga membuat data perkembangan peserta didik serta memotivasi peserta didik agar lebih semangat dalam mengikuti pembelajaran penjas adaptif.

\section{Guru kelas}


Membuka pembelajara guru dalam membuka pelajaran, memberikan motivasi dan menyampaikan tujuan pembelajaran. Namun, SLB Negeri Sragen saja yang mendampingi peserta didik melakukan pemanasan sebelum melakukan pembelajaran. Pengunaan metode menggunakan metode pembelajaran yang sesuai dengan kebutuhan peserta didik dan jenis ketunaannya. fasilitas pembelajaran untuk penjas adaptif di SDLB Kabupaten Sragen sudah tersedia. Namun, belum ada fasilitas yang mendukung secara khusus jenis ketunaan peserta didik. Guru penjas sudah memiliki kompetensi yang baik dalam membelajarkan penjas adaptif di sekolah. Guru juga berupaya membuat pembelajaran yang menyenangkan bagi peserta didik. Pelaksanaan pembelajaran sudah melakukan pembelajaran dengan baik dan memfasilitasi pembelajaran penjas adaptif dengan baik. Guru juga melakukan evaluasi dan melakukan refleksi setiap akhir pembelajaran. Dukungan orang tua murid semua orang tua wali mendukung anaknya dalam proses pembelajaran dengan mengantar dan menjemput anak ke sekolah. Pembelajaran penjas adaptif sangat berpengaruh positif dn memberikan perubahan sikap yang baik pada peserta didik. Sarana prasarana minimal di SDLB Kabupaten Sragen sudah mencukupi. Akan tetapi, SLB Swasta cenderung sarana prasarananya masih kurang dibanding SLB Negeri.

\section{Wali Murid}

Sikap anak setelah menerima pembelajaran terjadi perubahan sikap yang lebih baik pada peserta didik di SDLB Kabupaten Sragen setelah mengikuti pembelajaran penjas adaptif. Oleh karena itu, pembelajaran penjas adaptif yang ideal, kondusif sangat baik ditingkatkan dan terus dilakukan perbaikan di segala sisi di SDLB Kabupaten Sragen.

\section{Simpulan}

Pelaksanaan pembelajaran penjas adaptif di SDLB Kabupaten Sragen sudah tergolong baik. Pembelajaran dilakukan sesuai dengan jenis ketunaan peserta didik. SDLB di Kabupaten Sragen mayoritas sudah memiliki fasilitas sarana prasarana dasar penunjang pelaksanaan pembelajaran penjas adaptif. Sarana prasarana pembelajaran penjas adaptif diantaranya: bola besar, bola kecil, con, bosi, alat atletik, dan lapangan.

Pelaksanaan pembelajaran di YPSLB Gemolong, SLB B-C Bagaskara dan SLB Negeri Sragen sudah memisahkan pembelajaran berdasarkan jenis ketunaan peserta didik. Namun, pelaksanaannya masih belum maksimal dan kondusif karena guru mengalami kesulitan dalam mengendalikan peserta didik. 
Nur Alim, Arif Rohman Hakim, Karlina Dwijayanti

Sarana prasarana di sekolah mayoritas sudah baik. Di SLB B-C Bagaskara dan SLB Negeri Sragen sudah memiliki fasilitas sarana prasarana penunjang pembelajaran penjas adaptif. Tetapi, di YPSLB Gemolong sarana prasarana belum terlalu lengkap. Di YPSLB belum tersedia lapangan untuk tempat bermain, olahraga, dan upacara secara khusus dan terpisah. Peralatan atletik pun juga belum lengkap, sehingga agak susah untuk melaksanakan pembelajaran secara maksimal.

\section{Referensi}

Atmaja, Jati Rinarki. 2019. Pendidikakan Dan Bimbingan Anak Berkebutuhaan Khusus. Bandung: Penerbit Remaja Rosdakarya.

Hakim, Arif Rohman. 2017. Memuliakan Anak Berkebutuhan Khusus Melalui Pendidikan Jasmani Adaptif. Jurnal Ilmiah PENJAS, ISSN: 2442-3874 Vol.3 No.1. Januari 2017. . 2017. Pendidikan Jasmani Adaptif. Surakarta: Universitas Tunas

Pembangunan.

Kemis dan Ati Rosnawati. 2013. Pendidikan Anak Berkebutuhan Khusus Tuna Grahita. Jakarta: Luxima Metro Media.

Melinda, Elly Sari. 2013. Pembelajaran Adaptif Anak Kebutuhan Khusus. Jakarta: Luxima Metro Media.

Sugiyono. 2018. Metode Penelitian Kuantitatif, Kualitatif, Dan R\& D, Bandung: Alfabeta. Tarigan, Beltasar. 2013. Pendidikan Jasmani Adaptif. Bandung: UPI POK/PJKR. 2016. Pendidikan Jasmani Adaptif. Bandung: UPI.

Yani dan Caryoto. 2013. Media Pembelajaran Adapif bagi Anak Berkebutuhan Khusus. Jakarta: Luxima Metro Media. 